\title{
ELECTRO-GRAVIMETRIC RECOVERY OF SILVER FROM AQUEOUS SOLUTIONS AND ITS PRECURSORS
}

\author{
Afzal Shah ${ }^{1,2^{*}}$, Sirajuddin ${ }^{3}$, Imdad Ullah ${ }^{1,4}$ and Afzal Shah ${ }^{4}$ \\ ${ }^{1}$ School of Chemistry, Monash University, Clayton Campus, Melbourne, VIC 3800, Australia \\ ${ }^{2}$ Department of Chemistry, University of Science and Technology, Bannu 28100, Khyber \\ Pakhtunkhwa, Pakistan \\ ${ }^{3}$ National Center of Excellence in Analytical Chemistry, University of Sindh, Jamshoro, \\ Pakistan \\ ${ }^{4}$ Department of Chemistry, Quaid-i-Azam University, Islamabad, Pakistan
}

(Received June 28, 2014; revised October 13, 2015)

\begin{abstract}
A simple electrolytic cell was used for electrochemical recovery of silver from aqueous solutions containing $100 \mathrm{mg} / \mathrm{L} \mathrm{Ag}(\mathrm{I})$. Two different sets of electrodes were applied to find the enhanced recovery of silver. Rocks and ores samples were processed through fire assay method and acid digestion. A set of electrodes comprised of stainless steel anode and aluminum cathode gave maximum recovery $(96.5 \%)$ of silver. This simple, robust, environment friendly and highly sensitive method was effectively applied to various ores and rock samples. The developed method with slight modifications can also be applied for the recovery of other metals.
\end{abstract}

KEY WORDS: Boulangerite ore, Deposition, Electrolytic cell, Electrodes, Recovery, Silver

\section{INTRODUCTION}

Silver metal is considered among the precious metals because it is a high value product and distinctive with supplies. It is referred as a catalyst, precursor and industrially important. The rare existence and high demands by community make it expensive because the production and demands do not correspond to each other $[1,2]$.

Precious metal clay (PMC) corresponds to a remarkable development in the management of precious metals. PMC consists of very small particles up to 20 micron size. It contains silver or gold floating in an organic binder to generate a flexible material with uniformity and similar to modeling clay. PMC can be gently prepared in a laboratory with the use of some cost effective, simple and traditional tools. At very high temperatures the organic binder isoxidized by burning and the metal particles blend to form solid metal which can be fused, rubbed down, highlighted by dying and polished just like the conventional substances [3]. Silver has wide range of applications and significantly used in dental and medical professions to treat different diseases for example cancer, arthritis and production of denture. The radio-therapeutic uses of silver are of great importance too. Industrially, silver is useful in the preparation of utensils, formation of ceramics and polishing/manufacturing of mirrors. Moreover, silver is used for monetary, decorative and jewellery purposes. Silver is also used in X-ray photography, medicine $\left(\operatorname{Ag}_{2} \mathrm{O}\right.$, $\mathrm{AgNO}_{3}$, Argyrols), bactericide, antiseptic, oil and water purifier $\left(\mathrm{Ag}_{3} \mathrm{PO}_{4}\right)$. In tableware, electric components, circuits, stable electrodes, medals and batteries silver is applied as a conductor and corrosion resistant metal [4-6].

In Pakistan three main types of rocks like igneous/magmas rocks, sedimentary rocks and metamorphic rocks are important for getting significant quantities of precious metals like silver. The processes involved in recovery of metals from their respective ores depend on their mineralization, chemical and physical properties as well mode of occurrence in ore deposits. Silver occurs in association with Au deposits; as metamorphic, hydrothermal and substitution

*Corresponding author. E-mail: afzalnm@yahoo.com 
deposits or exists as lumps and granules in residual deposits. Mostly silver exists in alloy form with gold and other metals. Generally, silver is associated with sulfides of $\mathrm{Fe}, \mathrm{As}, \mathrm{Cu}$ as well compounds of antimony and selenium [7].

Cyanide leaching, activated carbon and thiourea methods have been applied for effective leaching, adsorption and desorption of precious metals. In this regard an electrolytic cell holding a set of stainless steel cathode and stainless steel anode has been utilized. Moreover, different procedures like recycling, cementation and quartation have been adopted to recover precious metals, e.g. Ag and Au [8]. Reyes-Cruz et al. have reported the cell voltage value of $1.4 \mathrm{~V}$ for silver recovery from cyanide leaching solution using three electrode systems [9]. Luna-Sanchez has described the cell voltage value of $1.2 \mathrm{~V}$ for leaching behavior of silver from sulfide concentrates [10].

The present studies were aimed to evaluate some fundamental parameters for the electrodeposition and recovery of silver from standard aqueous solutions, ore and rock samples. This study was designed to use the cost effective and less toxic chemicals as well as develop a simple, economical and environment friendly method for silver ions deposition.

\section{EXPERIMENTAL}

\section{Equipment and apparatus}

$\mathrm{pH}$ meter, model inoLab of WTW (GMBH, Germany) was used for $\mathrm{pH}$ measurements. Pipetman Micropipettes (Gilson, USA) of variable ranges were used for micro volume adjustments of the solutions. The electro-winning experiments were performed with simple electrolytic cell consisted of a beaker and two sheet electrodes (anode and cathode). The solution was stirred with a magnetic follower of $1 \mathrm{~cm}$ bar. Two different sets of static sheet electrodes, i.e. stainless steel anode and stainless steel cathode (SASC) as well stainless steel anode and aluminum cathode (SAAC) were used as electrode couples. DC power supply was used as a source of current and multi-meter worked as a mean of measuring the cell voltage. An electric oven (Thermo Scientific, USA) and desiccators were used for drying and cooling of glass apparatus and electrodes. Precisa balance model XB 120A (Switzerland) was used for weighing purpose.

\section{Chemicals and reagents}

All chemicals were of high purity analytical grade, purchased from Fluka, Sigma-Aldrich, and Fisher Scientific International Companies. For routine analytical work fresh standard aqueous solutions of $\mathrm{Ag}(\mathrm{I})$ ions were prepared by dissolving silver nitrate $\left(\mathrm{AgNO}_{3}\right)$ in double distilled water using amber bottles because silver nitrate solutions are light sensitive. $2 \mathrm{M}$ glacial acetic acid $\left(\mathrm{CH}_{3} \mathrm{COOH}\right)$ and $2 \mathrm{M}$ sodium acetate $\left(\mathrm{CH}_{3} \mathrm{COONa}\right), 3 \mathrm{M}$ nitric acid $\left(\mathrm{HNO}_{3}\right), 0.005 \mathrm{M}$ ammonia $\left(\mathrm{NH}_{3}\right)$ were also prepared in double distilled water, respectively.

\section{Sampling profile}

Table 1 shows various samples collected from different regions of Pakistan. The samples are classified on the bases of nature of rocks present in the respective region of sample collection. The nature of the rock type in sampling points is defined by the Geology Department of Sindh University, Jamshoro while the boulangerite ore was obtained from Mineral Testing Laboratories directly. 
Table 1. Sampling sites from various regions of Pakistan.

\begin{tabular}{|c|c|c|c|}
\hline $\begin{array}{l}\text { Sample } \\
\text { code }\end{array}$ & Site of collection & Physical appearance & Remarks \\
\hline $\mathrm{R}_{1}$ & BakkaKhail (NWA) & Brownish & \multirow{5}{*}{$\begin{array}{l}\text { Sedimentary and } \\
\text { metamorphic } \\
\text { basic rocks }\end{array}$} \\
\hline $\mathrm{R}_{2}$ & Miran Shah (NWA) & Purple & \\
\hline $\mathrm{R}_{3}$ & Mir Ali (NWA) & Dark gray & \\
\hline $\mathrm{R}_{4}$ & Karak (KPK) & Gray & \\
\hline $\mathrm{R}_{5}$ & Dara Pezzo (KPK) & Dark brown & \\
\hline \multicolumn{4}{|c|}{ Samples collected from PCSIR Laboratories Karachi (Sindh) } \\
\hline $\mathrm{R}_{6}$ & \multirow{3}{*}{ JamKhanjoVandio (Sindh) } & Pink & \multirow{3}{*}{ Igneous rock } \\
\hline $\mathrm{R}_{7}$ & & Dark blue & \\
\hline $\mathrm{R}_{8}$ & & Light blue & \\
\hline $\mathrm{R}_{9}$ & \multirow{3}{*}{ Ramji jo Vandio (Sindh) } & Dark green (Malenocratic) & Fine grain basic rock \\
\hline $\mathrm{R}_{10}$ & & Light pink (Leucocratic) & Coarse grain granite rock \\
\hline $\mathrm{R}_{11}$ & & Light pink (Leucocratic) & Coarse grain granite rock \\
\hline $\mathrm{R}_{12}$ & \multirow{4}{*}{ Paradaro (Sindh) } & Dark gray & \multirow{3}{*}{ Basic Rocks } \\
\hline $\mathrm{R}_{13}$ & & Light gray & \\
\hline $\mathrm{R}_{14}$ & & Gray & \\
\hline $\mathrm{R}_{15}$ & & Gray & Granite with feldlaths \\
\hline $\mathrm{R}_{16}$ & Mukrio & Dark green (Hyper malenium) & Basic rock \\
\hline $\mathrm{R}_{17}$ & Kasbo & Dark green (Hyper malenium) & Basic rock \\
\hline $\mathrm{R}_{18}$ & \multirow{2}{*}{ On jo Vandio (Sindh) } & Dark red & \multirow{3}{*}{$\begin{array}{l}\text { Ferrogenous sand stone } \\
\text { of Barthala formation }\end{array}$} \\
\hline $\mathrm{R}_{19}$ & & Yellow & \\
\hline $\mathrm{R}_{20}$ & Zardari Mine Nagar Parkar & Dark red & \\
\hline \multicolumn{4}{|c|}{ Ores samples collected from Mineral Testing Laboratories (MTL) Peshawar (KPK) } \\
\hline & Ore sample & Chemical composition & Color \\
\hline 1 & Boulangerite & $\mathrm{Pb}_{5} \mathrm{Sb}_{4} \mathrm{~S}_{11}$ & Blue and grey to brown \\
\hline
\end{tabular}

NWA $=$ North Waziristan Agency, KPK $=$ Khyber Pukhtunkhwa.

\section{Sample treatment}

The ores and rock samples were crushed and grinded in a jaw crusher and ball mills to convert them into powder form. The powdered samples 80 micron mesh sizes were then processed by fire assay method. Regarding the raw materials, most of the antimony, sulfur, and lead contents were escaped in the form of unstable volatile oxides using fire assay method as mentioned earlier. The ash contents of ores and rocks samples were processed by acid $\left(\mathrm{HNO}_{3}\right)$ digestion processes. The acid was evaporated by heating the sample solutions. The sample solutions were then diluted with double distilled water up to the desired concentrations $(100 \mu \mathrm{g} / \mathrm{mL})$ of $\mathrm{Ag}(\mathrm{I})$. The $\mathrm{pH} 5.7$ of the stock solution was adjusted by using acetate buffer system.

\section{Methodology}

In this method the electro active species were deposited on the surface of electrode from aqueous solutions under the influence of applied cell voltage in the presence of electrolyte with properly controlled other parameters. The electrolytic deposit must be metallic, shining and easily scratchable in nature. In case of electroplating, the deposit must be thin, unscratchable, stable and resistant to the attack of various reagents. According to the procedure an appropriate amount of solution with fixed concentration of $\mathrm{Ag}(\mathrm{I})$ and buffer system was taken in a simple electrolytic cell, i.e. beaker. The pre-weighed static sheet electrodes i.e. cathode and anode were attached to a DC power supply and multi-meter through copper wires. The electrodes were hanged into the solution up to a particular depth. Thus, the solution was electrolyzed by switching on the power supply under proper settings of cell voltage, stirring rate, electrodes 
separation, $\mathrm{pH}$, temperature, supporting electrolyte and time of electrolysis. After the completion of electrolysis and convection, the electrodes were fetched out of the cell, disconnected from copper wires, dried in an electric oven for $5-10 \mathrm{~min}$ at $110{ }^{\circ} \mathrm{C}$, cooled to room temperature in desiccators and re-weighed. The difference between previous and final weights of the cathode gave the actual amount of metal concerned.

Ag analysis in ore/rock samples

Refer to Table 1 , the sample solutions of boulangerite ore and rocks $\left(R_{1}-R_{3}\right)$ were quantitatively analyzed for Ag (I) using atomic absorption spectrometry (AAS). Standard addition method and linear regression line were used for calibration purpose. The average amount of $A g(I)$ in various sample solutions was determined in the range of $18-33 \mu \mathrm{g} / \mathrm{mL}$. The concentrated sample solutions were used as analyte solutions for $\mathrm{Ag}(\mathrm{I})$ recovery.

\section{RESULTS AND DISCUSSIONS}

The electro-winning of silver metal is affected by various operational parameters and nature of electrolytic cell as described below.

\section{Effect of cell voltage}

The effect of cell voltage was optimized because various cationic and anionic species respond to particular electrodes voltages on the surfaces of electrodes. Hence, different electrode potentials contribute to a particular cell voltage which affects the nature of the deposited metal. The chemical composition of the solution near the electrodes responds to interfacial voltage difference at the corresponding electrode. Any change in the cell voltage changes the capability of working electrode. In this case the aqueous solution contains $\mathrm{H}^{+}, \mathrm{Ag}^{+}, \mathrm{NO}_{3}$ and $\mathrm{OH}$. Hence, two types of chemical reactions occur at the surfaces of electrodes [11].

Cathodic reaction:

$\mathrm{Ag}(\mathrm{I})+\mathrm{e}^{-} \longrightarrow \mathrm{Ag}(0)$

$\mathrm{H}^{+}$and $\mathrm{Ag}(\mathrm{I})$ compete on the surface of cathode. Ag (I) ions have higher reduction potential as compared to $\mathrm{H}^{+}$ions. Thus, higher the reduction potential greater will be the tendency to reduce. Hence, silver is deposited on the surface of cathode more readily as compared to hydrogen.

Anodic reaction

$4 \mathrm{OH}^{-} \longrightarrow 2 \mathrm{H}_{2} \mathrm{O}+\mathrm{O}_{2}$

$\mathrm{NO}_{3-}^{-}$and $\mathrm{OH}^{-}$compete on the surface of anode. $\mathrm{OH}^{-}$ions have higher oxidation potential than $\mathrm{NO}_{3}$ ions and liberate on the surface of anode forming water and molecular oxygen.

Figure 1 shows results for percent recovery of silver from standard aqueous solutions (prepared in laboratory) using a set of electrodes couples, i.e. "SASC" and "SAAC". The maximum \% recovery $(58.6 \pm 0.2)$ of silver was obtained at optimum cell voltage of $1.5 \mathrm{~V}$ using "SAAC" electrodes couple. The deposit was with sharp metallic and shinning properties. While the smaller recovery on others cell voltage values and electrodes couple "SASC" were nonscratchable and powdery in characters and hence, the deposit was not suitable to get silver directly. Although, at optimized cell voltage of $1.5 \mathrm{~V}$ and electrodes couple "SAAC" the deposited $\operatorname{Ag}(0)$ was not only metallic and shinning in characters but also easily scratchable. In 
the literature, different assembling of electrochemical cells set-up was used to recover silver. While in current studies two electrodes system was used for electro-deposition of silver and cell voltage $1.5 \mathrm{~V}$ was observed optimum cell voltage for maximum $\%$ recovery of silver [9-10].

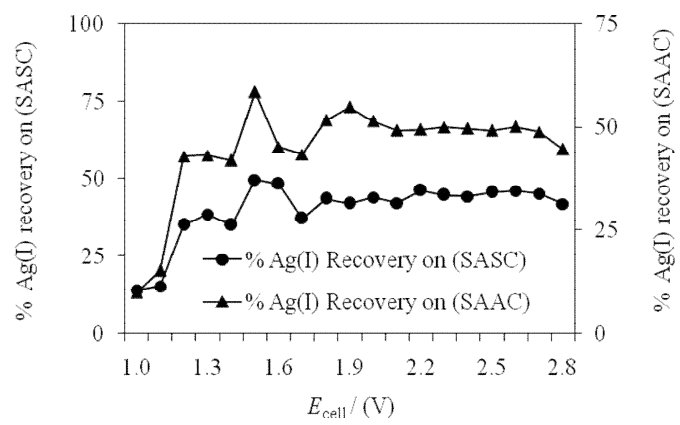

Figure 1. Cell voltage (V) versus \% cathodic $\operatorname{Ag}(0)$ recovery; a set of electrodes couples (SASC) and (SAAC); $\operatorname{Ag}(\mathrm{I})$ concentration, $100 \mu \mathrm{g} / \mathrm{mL} ; \mathrm{pH}, 5.7 \pm 0.1$; depth area of electrode, $1.9 \times 3.7 \mathrm{~cm}^{2}$; separation between electrodes $1 \mathrm{~cm}$; deposition time, $20 \mathrm{~min}$; temperature, $25 \pm 1{ }^{\circ} \mathrm{C}$; stirring rate, $200 \mathrm{rpm} ; 0.2 \mathrm{M}$ acetate buffer with $0.005 \mathrm{M} \mathrm{NH}_{3}$ as supporting electrolytes and $\mathrm{pH}$ adjuster.

pHstudy

$\mathrm{pH}$ studies were carried out for maximum \% recovery of silver using appropriate buffer system for $\mathrm{pH}$ adjustments because any change in $\mathrm{pH}$ causes variations in the $\%$ recovery of silver. $\mathrm{pH}$ greatly influence the solubility of metals and conductivity of the electrolytic system. Thus, an optimum $\mathrm{pH}$ value is required for maximum electro-deposition of metal to yield greater $\%$ recovery. The effect of different electrolytes systems was investigated for maximum \% recovery of silver. The acetate buffer system was chosen best for greater recovery of silver. Figure 2 shows the \% recovery of silver at different $\mathrm{pH}$ values and different electrodes couples. Different volumes of $0.2 \mathrm{M} \mathrm{CH}_{3} \mathrm{COOH}$ and $\mathrm{CH}_{3} \mathrm{COONa}$ with $0.005 \mathrm{M} \mathrm{NH}_{3}$ were used for $\mathrm{pH}$ adjustment. The optimum value of $\mathrm{pH} 6.1$ was selected best for maximum \% recovery $(60.5 \pm 0.7)$ of silver using "SAAC" electrodes couple while $\mathrm{pH}$ value 6.0 was true for maximum \% recovery of silver using "SASC" electrodes couple. However, the former $\mathrm{pH}$ was selected for further studies due to very little difference in the \% recovery of silver at later electrodes couple. The very less acidic $\mathrm{pH}$ in our case is thus suitable for minimum acid attack on working electrodes which are present in the electrochemical cell for a longer period of electrolysis. The less acidic $\mathrm{pH}$ can be significant to minimize the chances of hydrogen bubbling and hence improve the $\%$ recovery of silver. It was also observed that deposition of silver at lower $\mathrm{pH}$ values lost metallic behavior and existed in slightly powdery and coarse appearance. This may be due to the concentration polarization as higher amounts of hydronium ions come on the surface of electrode at lower $\mathrm{pH}$ values. Moreover, acidic $\mathrm{pH}$ also causes the passivation of anode due to formation of salts on its surface and release of free acids. However, very basic $\mathrm{pH}$ media cause generation of oxygen or oxides which may lead to passivation of anode surface [8]. Luna-Sanchez et al. have reported that $\mathrm{pH} 10.6$ gives maximum leaching of silver from sulfide concentrates [10]. Reyes-Cruz et al. have recommended $\mathrm{pH} 10$ for electrochemical deposition of silver and gold from cyanide leaching solutions [12]. Alireza and Mohammad have investigated $\mathrm{pH} 9.0-10.5$ for the 
accumulation of silver on carbon past electrode [13]. Mi-Sook et al. have studied deposition of silver on pH 6.0 using citric acid/sodium citrate buffer [14]. Radka et al. have used an acetate buffer with $\mathrm{pH} 5.0$ for the deposition of silver on glassy carbon electrode applying stationary and flow injection electrochemical techniques [15].

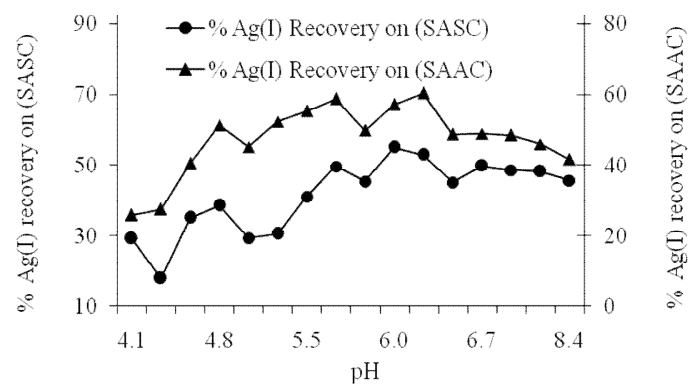

Figure 2. $\mathrm{pH}$ versus \% cathodic $\mathrm{Ag}(0)$ recovery; cell voltage $1.5 \mathrm{~V}$; all other parameters are same as for Figure 1.

\section{Stirring rate effect}

Stirring causes convection of ions in the direction of working electrode. The optimum stirring rate is valuable for getting smooth and maximum recovery of metals because very high stirring rates may remove some of the loose deposit from the surface of the electrode. Figure 3 shows variation in \% recoveries of silver at various stirring rates. It can be seen from Figure 3 that \% recovery of silver initially increases with the increase in stirring rate up to $400 \mathrm{rpm}$ and $500 \mathrm{rpm}$ at "SASC" and "SAAC" electrodes couples respectively and decreases thereafter. It may be due to the scratching of some wobbly deposits formed on the surface of electrode. It was also noticed that very high rate threw off the solution from the electrolytic cell along with some loose deposits from the surface of electrode and hence disturbed the quantity of silver ions within the cell or on the surface of electrode which may decrease \% recovery of silver. Mi-Sook et al. have reported $600 \mathrm{rpm}$ stirring rate for deposition of silver on modified carbon paste electrode [14]. Mojtaba et al. have also recommended the use of stirring for the electro-recovery of silver but they have not mentioned the best stirring rate [16]. Clinio has reported $600 \mathrm{rpm}$ stirring rate for deposition of platinum group metals [17]. Other researchers have also employed stirring for deposition of metals on different types of electrodes [18]. In current studies the stirring rate of $400 \mathrm{rpm}$ was chosen as optimum stirring rate for getting metallic, shinning, scratchable silver with maximum $\%$ recovery of $70.1 \pm 1.0$ using "SAAC" electrodes couple.

\section{Separation of electrodes}

The effect of distance between electrodes was studied for maximum deposition of silver. Figure 4 indicates that \% recovery of silver is decreasing with increase in the separation of electrodes. Researchers have studied the effect of distance between electrodes on the experimental consequences. They reportedthat an increase in distance between electrodes has adverse affect on the experimental consequences as the distance between the set of electrodes increases the experimental response decreases [19-20]. It can be explained as the electrical field generated between two electrodes may become less intense due to the lengthening of distance for current flow between two electrodes when they are distant from each other. The distance between the set of electrodes also influences the electrical resistance. The resistance between two electrodes increases when they are carried away to some distance. Hence, due to high resistance the amount of silver deposition may be reduced and vice versa. 


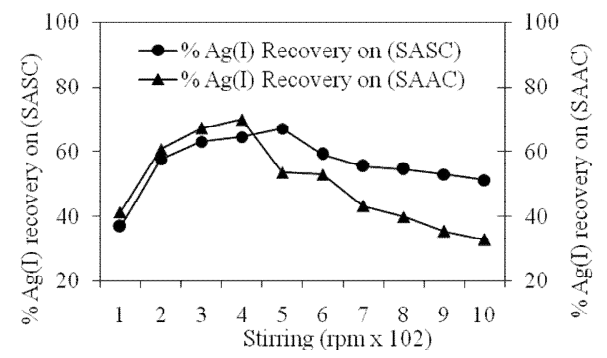

Figure 3. Stirring rate $(\mathrm{rpm})$ versus \% cathodic $\operatorname{Ag}(0)$ recovery; cell voltage $1.5 \mathrm{~V} ; \mathrm{pH}$ 6.1. All others parameters are same as for Figure 1.

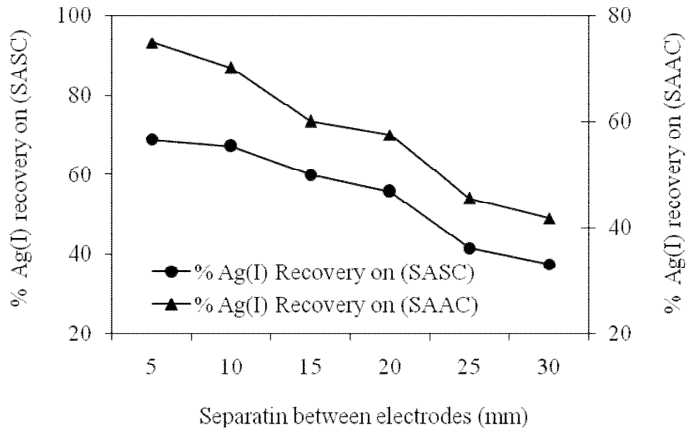

Figure 4. Separation between electrodes $(\mathrm{mm})$ versus \% cathodic $\operatorname{Ag}(0)$ recovery; cell voltage $1.5 \mathrm{~V} ; \mathrm{pH} 6.1$; stirring rate, $400 \mathrm{rpm}$. All others parameters are same as for Figure 1.

\section{Temperature effect}

In continuation to previously optimized parameters, temperature was also optimized to get maximum \% recovery of silver. Figure 5 indicates that \% recovery of silver occurs in a slightly linear manner and increases with increase in temperature from $25-45^{\circ} \mathrm{C}$ but decreases beyond $45{ }^{\circ} \mathrm{C}$ subsequently. The gradual increase up to $45{ }^{\circ} \mathrm{C}$ may be due to the convection property which enhance the mobility of silver ions towards cathode and increase its deposition on the surface of cathode. The decrease in $\%$ recovery of silver after $45^{\circ} \mathrm{C}$ may be due to the evaporation of electrolyte contents (acetate buffer and ammonia) owing to its volatile nature. The evaporation of electrolytes may result in the imbalance of silver complex, conductivity of the solution and hence reduced \% cathodic recovery of silver. Hence, temperature $45{ }^{\circ} \mathrm{C}$ was chosen as an optimum temperature for maximum \% recovery $(83.6 \pm 1.3)$ of silver. It was also observed that at this temperature the deposited silver was more lustrous and metallic in nature. Researchers have described room temperature for electro-recovery and deposition of silver [913]. Mi-Sook et al. have reported that deposition of silver on modified carbon paste electrode in a media of citric acid/sodium citrate buffer is increasing in a nearly linear fashion with increase in temperature from $25-35{ }^{\circ} \mathrm{C}$, however at temperatures above $40{ }^{\circ} \mathrm{C}$ it is decreasing due to the roughness of the electrode surface with slow dissolution of the complex into the bulk solution [14]. Scientists have also recommended room temperature for the deposition of rare metals [15, 
21]. Hosny has reported temperature range of $25-55^{\circ} \mathrm{C}$ for electro-deposition of silver on carbon past electrode using potentiometric flow injection technique [22]. Afzal et al. have reported that at higher temperature the evaporation of water could also contribute to the problem of anodic passivation. He also stated thatevaporation of larger amount of water from the solution matrix may result into increasing the viscosity of the solution which in turn slow the mobility of silver ions and hence decrease the percent recovery [8]. Sathaiyan et al. have studied the effect of temperature in a range of $30-75^{\circ} \mathrm{C}$ for extraction of silver. They observed that extraction of silver increases with rise in temperature and marginal beyond $50{ }^{\circ} \mathrm{C}[23]$.

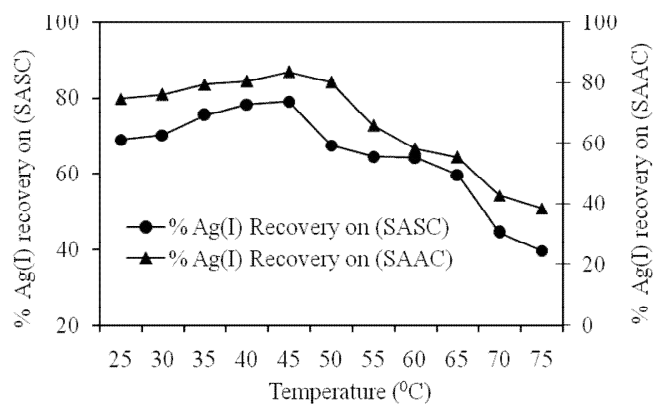

Figure 5. Temperature $\left({ }^{\circ} \mathrm{C}\right)$ versus \% cathodic $\operatorname{Ag}(0)$ recovery; cell voltage $1.5 \mathrm{~V} ; \mathrm{pH} 6.1$; stirring rate, $400 \mathrm{rpm}$. All others parameters are same as for Figure 1.

\section{Electrolysis time effect}

Electrolysis time was optimized in the range of 10 to $60 \mathrm{~min}$ to get greater recovery of silver. It is evident from Figure 6 that \% recovery of silver gradually increases in a nearly linear mode from 10 to $60 \mathrm{~min}$. Electrolysis time of $50 \mathrm{~min}$ was found best for maximum deposition of silver with more metallic properties. In this case the maximum \% recovery $(99.5 \pm 0.4)$ of silver was obtained on "SAAC" electrodes couple. The deviation from linearity may be due to the phenomenon of concentration polarization and deficiency of metal ions in the bulk solution. According to some researchers as the time progresses, the electrolytic processes are not controlled by diffusion and other forces weaker than diffusion which are not stronger enough to carry the electrolysis at continuously increasing rate [24-25]. So, the decrease in \% recovery of silver at higher electrolysis times may be due to the limitation of silver ions in the solution matrix and narrow mobility of metal ions toward the cathode. Others researchers have reported different electrolysis time ranges, i.e. $30 \mathrm{~s}$ to $24 \mathrm{~min}$ for the electro-deposition of metals, depending upon the composition of electrolytic cell set-up and instrumentation [9, 26-27].

\section{Application of method to samples}

The optimized method was applied to sample solutions of different ores and rocks (see sampling profile in experimental section). The ores and rocks samples were concentrated up to the desired concentration of silver ions. Thus, it was found that average \% recoveries of silver from Boulangerite ore, $R_{1}, R_{2}$ and $R_{3}$ rocks samples were $96.5 \%, 95.8 \%, 94.9 \%$ and $95.5 \%$, respectively. 


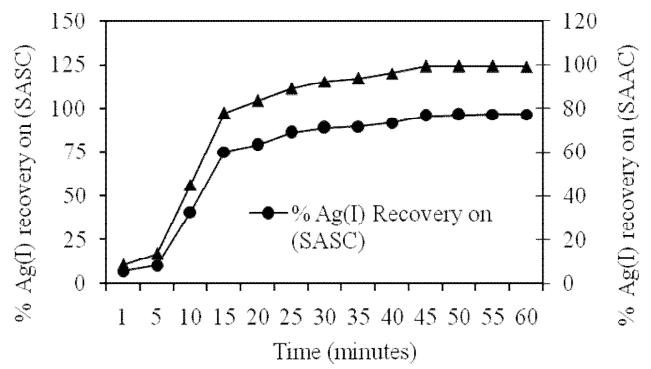

Figure 6. Electrolysis time (min) versus \% cathodic $\operatorname{Ag}(0)$ recovery; temperature, $45 \pm 1{ }^{\circ} \mathrm{C}$; cell voltage $1.5 \mathrm{~V} ; \mathrm{pH} 6.1$; stirring rate, $400 \mathrm{rpm}$. All others parameters are same as for Figure 1.

\section{CONCLUSION}

The described process can be very significant if applied to refractory ores and rocks in order to recover silver from them on industrial scale. In this study, various parameters like cell voltage, $1.5 \mathrm{~V} ; \mathrm{pH}, 6.1 \pm 0.1$; depth area of electrode, $1.9 \times 3.7 \mathrm{~cm}^{2}$; separation between electrodes, $5 \mathrm{~mm}$; deposition time, $50 \mathrm{~min}$; temperature, $45 \pm 1{ }^{\circ} \mathrm{C}$; stirring rate, $400 \mathrm{rpm}$; whereas, $0.2 \mathrm{M}$ acetate buffer and $0.005 \mathrm{M} \mathrm{NH}_{3}$ as supporting electrolytes and $\mathrm{pH}$ adjusters were found best conditions for maximum recovery of silver. Electrodes couples like "SASC" and "SAAC" were comparatively applied to evaluate the maximum deposition of $\operatorname{Ag}(0)$. Electrodes couple "SAAC" gives maximum \% recovery of silver with more metallic and shining properties. It was also noticed that highly basic $\mathrm{pH}$ values and very acidic solution favor loose and powdery deposition as well cause the passivation of anode and dissolution of acid soluble electrode bodies. As compared to standard aqueous solutions, the reduced \% recovery of silver from ore and rocks $\left(\mathrm{R}_{1}-\mathrm{R}_{3}\right)$ samples may be due to the presence of some micro-level impurities and coexisting metals which interfere with the deposition of silver at steel and aluminum cathodes, respectively.

\section{REFERENCES}

1. Bekir, S.; Omur, C.; Serhat, D.; Mehmet, D. Anal. Chim. Acta 2007, 587, 272.

2. Afzal, S. Electrochemical Evaluation and Recovery of Precious Metals Present in some Pakistani Ores and Rocks, NCEAC, University of Sindh: Pakistan; 2008.

3. Mark, G. Introduction to Precious Metals, A \& C Black: London; 2010; p 2.

4. Izhar, U.H.K.; Iffat, T.S. Pak. J. Sci. Indust. Res. 2010, 53, 233.

5. Cox, M.; Pichugin, A.A.; El-Shafey, E.I.; Appleton, Q. Hydrometall. 2005, 78, 137.

5. Harper, M.; Siegel, J.M. J. Air Waste Manag. Asso. 2003, 53, 434.

6. Kazmi, A.H.; Abbas, S.G. Metallurgy and Mineral Deposits of Pakistan, 1st ed., Orient Petroleum Incorporation, Hayat Hall: Islamabad; 2001; $p 120$.

7. Afzal, S.; Sirajuddin; A.N.; Bhanger, M.I.; Jamali, M.K. Acta Chim. Slov. 2007, 54, 907.

8. Reyes, C.V.; González, I.; Oropeza, M.T. Electrochim. Acta 2004, 49, 4417.

9. Luna, S.R.M.; Gonzalez, I.; Lapidus G.T. J. Appl. Electrochem. 2002, 32, 1157.

10. Ajay, K. Numerical Chemistry, Tata McGraw Hill Education Private Limited: New Delhi; 2012; p 400.

11. Reyes, C.V.; Ponce-de-Leo'n, C.; Gonza'lez, I.; Oropeza, M.T. Hydrometall. 2002, 65, 187.

12. Alireza, M.; Mohammad, T.A. Talanta 2007, 71, 615.

13. Mi-Sook, W.; Jeong-Sik, Y.; Jang-Hee, Y.; Euh-Duck, J.; Yoon-Bo, S. Bull. Korean Chem. Soc. 2003, 24, 948. 
14. Radka, M.; Vojtech, A.; Libuse, T.; Petr B.; Ales, H.; Rene, K. Biomed. Papers 2005, 149, 17.

15. Mojtaba, S.; Javad, T.; Bahram, H.; Hashem, S. Talanta 2004, 64, 590.

16. Clinio, L. Anal. Chim. Acta 2006, 557, 70.

17. Sylwester, H.; Joanna, K.; Magdalena, K.; Jerzy, G. Electroanalysis 2005, 17, 299.

18. Linderholm, P.; Schoch, R.; Renaud, P. Transducers 03, The International Conference on Solid State Sensors, Actuators and Microsystems: Boston; 2003, 12, 284.

19. Breguncci, V.A.L.; Martins, A.H.; Ribeiro, C.P. Miner. Metallur. Process. 2001, 18, 49.

20. Osipova, E.A.;Sladkov, V.E.; Kamenev, A.I.;Shkinev, V.M.;Geckeler K.E. Anal. Chim. Acta 2000, 404, 231.

22. Hosny, I. Anal. Chim. Acta 2005, 545, 158.

23. Sathaiyan, N.;Nandakumar, V.; Ramachandran, P. J. Power Source 2006, 161, 1463.

24. Reza, S.K.; Mohsen, B.K. Talanta 2006, 69, 741.

25. Pletcher, D. J. Appl. Electrochem. 2010, 40, 2203.

26. Masafumi, S.; Tomoyoshi, S.; Noboru, Y. Electr. Eng. Japan 2007, 158, 1.

27. Yi-Heng, L.; Hong-Qi, X.; Fang-Qin, Z. Talanta 2005, 67, 28. 